UDC $618.39-02-084$

DOI: 10.21668/health.risk/2020.1.17.eng

\title{
STRATIFICATION OF PRETERM BIRTH RISK: PECULIARITIES
}

\author{
M.M. Padrul' ${ }^{1}$, I.V. Galinova', A.A. Olina ${ }^{2}$, G.K. Sadykova' ${ }^{1}$ \\ ${ }^{1}$ Perm State Medical University named after E.A. Wagner, 26 Petropavlovskaya Str., Perm, 614000, Russian Federation \\ ${ }^{2}$ D.O. Ott's Scientific and Research Institute for Obstetrics, Gynecology, and Reproductology \\ 3 Mendeleevskaya line, Saint Petersburg, 199034, Russian Federation
}

According to the official statistics, in Perm region a number of preterm births (PB) has declined by $1.5 \%$ over the last 10 years; however, $P B$ is still a leading cause for neonatal mortality. Despite a lot of already performed research and studies that are being performed at the moment, there is still no clear understanding what etiological factors cause $P B$. The paper contains a literature review of research that focused on PB risk factors. Certain factors are generally recognized and included into "Preterm birth» clinical report (2013), but literature data analysis allowed revealing additional PB risk factors. Cervical incompetence (CI) is a generally recognized PB risk factor. In 2018 clinical recommendations were published; they contained a list of CI risk factors and some of them coincided with PB risk factors (bad habits, extreme anthropometric parameters, peculiarities in obstetric and gynecologic case history, certain extra-genital diseases, multiple pregnancy, application of assisted reproductive technologies, complicated pregnancy); some others are considered to cause only CI (application of anti-tumor hormonal preparations, CI in family case history, abnormal development and disorders in the structure of female genital organs, surgeries on ovaries in case history). We performed comparative analysis of $P B$ and CI risk factors and it helped us substantiate a necessity to create a unified list of PB risk factors as it would allow optimizing not only procedures applied to rank female patients but also accomplishing relevant $P B$ prevention.

Key words: risk factors, preterm birth, cervical incompetence, clinical report, клинические recommеndations, procedures for female patients ranking, preterm birth prevention, literature review, comparative analysis.

Research works that focus on preterm birth (PB) are performed quite continually and are still vital due to $\mathrm{PB}$ remaining the leading cause for neonatal deaths. We should note that over the last 10 years number of $\mathrm{PB}$ has reduced considerably. For example, according to data provided by obstetric hospitals, in Perm region preterm birth accounted for $7.5 \%$ in 2006 but the share declined to $6 \%$ by 2017 . In 2017 in Perm preterm births cases accounted for only $4.7 \%$ of the total number of births [1]. However, the most important thing is not a decrease in $\mathrm{PB}$ as it is but a change in delivery terms and a decrease in number of too early PB. This task is also being solved successfully despite new live birth criteria that were adopted in 2012; one of them is a pregnancy term being 22 weeks and more ${ }^{1}$. We analyzed official statistic data and revealed that there was a decrease in number of too early PB (22-27 weeks) in Perm region and they accounted for exceptionally low $0.5 \%$ in 2017 against $1.6 \%$ in 2006 [1]. All the achieved successes are undoubtedly due to new approaches implemented into everyday practice by both neona-

(C) Padrul'M.M., Galinova I.V., Olina A.A., Sadykova G.K., 2020

Mikhail M. Padrul' - Doctor of Medical Sciences, Professor, Head of the Obstetrics and Gynecology Department (e-mail: rector@psma.ru; tel.:+7 (342) 217-20-21; ORCID: http://orcid.org/0000-0002-6111-5093).

Irina V. Galinova - Post-graduate student at the Obstetrics and Gynecology Department (e-mail: rector@psma.ru, mishlanova1@mail.ru; tel.: +7 (342) 217-20-21;+7 (908) 243-58-63; ORCID: http://orcid.org/0000-0003-3558-0132).

Anna A. Olina - Doctor of Medical Sciences, Professor, First Deputy Director (e-mail: olina29@mail.ru; tel.: +7 (922) 329-53-62; ORCID: http://orcid.org/0000-0001-9101-7569).

Gul'nara K. Sadykova - Candidate of Medical Sciences, Associate Professor at the Obstetrics and Gynecology Department (e-mail: rector@psma.ru; tel.: +7 (342) 217-20-21; ORCID: http://orcid.org/0000-0003-1868-8336).

${ }^{1}$ On medical criteria of birth, certificate of birth and a procedure for issuing it: The Order by the RF Public healthcare and Social Development Ministry dated December 27, 2011 No. 1687n. Garant. Available at: http://base.garant.ru/70113066/ (17.09.2019). 
tologists and obstetricians and gynecologists; these new approaches are regulated by federal and regional regulatory documents.

Despite a great number of research works accomplished in the past and being accomplished at the moment, etiological factor that causes PB hasn't still been assuredly identified; several factors are known to play their roles in pathogenesis. They are activation of a mother's and/or fetus' hypothalamo-pituitaryadrenal axis; thrombophilia; uterine muscle overstretching caused by fetal hydrops, multiple pregnancy, or uterine malformations; local or systemic inflammation; ischemia; rejection of a transplanted fetus; etc. [2, 3]. It is extremely difficult to comparatively analyze results obtained by different authors due to different design of their works (prospect and retrospect studies; "case - control" studies; groups under comparison being created as per various risk factors, various $\mathrm{PB}$ types, and fetus mass; differences related to criteria that are included into a research work etc.) and due to different statistical analysis techniques applied in them (descriptive statistics; comparison between groups as per either absolute or relative values; parametric and non-parametric analysis; comparison based on calculating odds ratio (OR), relative risk (RR), $x^{2}$ criterion; regression analysis; etc.). Despite all the difficulties related to comparative analysis, we took an effort to estimate to what extent various factors influencing $\mathrm{PB}$ have indeed been examined so far.

Age. Chances that a woman might have PB depend on her age. Thus, PB chances grow insignificantly among women aged younger than 30 (OR 1.2-1.59 [4, 5]; RR 1.0-1.7 [6]). PB probability grows after a woman reaches 35 (OR 1.64-2.7); the worst forecast is for women older than 40 . Beta J. et al. note that women who are 45 years old run approximately 2 times higher PB risks that those who are just 20 [7].
But still, researchers tend to have different opinions on probable influence exerted by a woman's young age on PB risks. Some experts state that PB risk grows for women who are younger than 18 (by $2.2 \%$, $\chi^{2}=7.7 ; \mathrm{p}<0.01$ [8]); other believe that this increase in PB risks occurs when a woman is younger than 20 (OR 2.144 [4]; by $9 \%$ [9]; RR 2.5 [6]). There are also data that there is no dependence between young age and PB frequency [10]. Our colleagues don't confirm data on isolated impacts exerted by a woman's age on PB probability in their works [11].

We should note that the clinic protocol which is valid at present considers a woman's age younger than 18 and older than 34 to be a risk factor that causes $\mathrm{PB}^{2}$.

Several researchers consider a woman being an Afro-American a risk factor that leads to a 2-time increase in PB frequency [7, 12]. But other researchers disprove this fact. And it is disputable that this factor can have any significance for our country, so at present it is not included into the clinical protocol ${ }^{2}$.

Social factors. There are several works where it is noted that low socioeconomic status is a risk factor that can cause PB; the same data can be found in the clinical protocol. However, there are no precise criteria for assigning pregnant women into this risk category $^{2}$. Given that, it doesn't seem possible to apply this factor in everyday medical practice when a pregnant woman attends regular medical check-ups. The same goes for assessing impacts exerted by stress. Gravett M.G. et al noted that when a pregnancy is full-term, expression of placental adrenocorticotropic hormone is induced by fetal hypothalamo-pituitary-adrenal axis; and when a mother has a stress (either a physical or mental one), it is induced by stress mediators including hydrocortisone and adrenal and thus resulting in preterm expression of

\footnotetext{
${ }^{2}$ Preterm birth. Clinical recommendations (treatment protocol): The Letter by the RF Public Healthcare Ministry dated December 17, 2013 No. 15-4/10/2-9480 / approved by V.N. Serov, the President of the RF Obstetricians and Gynecologists Association, 2013, $20 \mathrm{p}$.
} 
placental adrenocorticotropic hormone. It stimulates placental estrogen and prostaglandin synthesis and ultimately causes PB [13]. This risk factor is also included into the clinical protocol but an obstetrician-gynecologist can't determine whether his patient has a stress in her life without specific tests which at present aren't regulated by any documents $^{2}$. In our opinion, should these risk factors be included, it could only make a ranking system more complicated and prevent from organizing efficient prophylaxis.

Next, we are going to dwell on certain social factors that were given some attention in literature but are not included into the protocol; still, their influence on PB risk is being examined at the moment. Thus, for example, there are data that unemployed women run higher PB risks (RR 4.0 [6]), 1.7 times higher risks [9]), and female students and clerks run similar risks (RR 1.0 and 1.3 accordingly. Casas M. et al analyzed 13 research works accomplished in Europe and revealed that PB risks was insignificantly lower for employed women (OR 0.86) but still depended on their occupation. Thus, for example, PB risk was on the contrary higher for women employed at food-making enterprises (OR 1.5) [14].

According to Yu.A. Semyonov et al., education is a significant factor as it influences a woman's behavior: how often and regularly she attends a doctor, how precisely she adheres to doctor's recommendations, and how persistent she is in pursuing healthy lifestyle which is necessary for pregnant women. Women with secondary education were met almost two times more frequently than women with higher education among those who had preterm birth. These results are also confirmed by a research work accomplished by N.Yu. Katkova et al.; they showed that absence of higher education resulted in greater $\mathrm{PB}$ risks (OR 4.64).

Yu.A. Semyonov et al. believe that marital status and age of coitarche also have their influence. Single women run 2 times higher PB risks; women who had their first sexual intercourse when they were younger than
16 run 3 times higher PB risks. However, it is the only research work available to us where we managed to find some data on influence exerted by age of coitarche [9]. Dyadichkina et al. didn't reveal any relation between marital status and PB probability [5].

Several authors state that PB depends on quality of prenatal observation; there is a 2.4 times growth in $\mathrm{PB}$ [15]; inadequate observation, OR 2.87-3.2; no observation at all, OR 3.0-5.19 [16].

Data on impacts exerted by physical loads are rather contradictory. Excessive physical loads during pregnancy as well as hypodynamia can influence $\mathrm{PB}$ frequency. The problem is that there are no common objective parameters of physical activity that can be applied when studying this risk factor for pregnant women $[17,18]$.

Bad habits. According to the clinical protocol, if a mother has bad habits (alcohol, nicotine, or drug dependence), it is a risk factor that can cause $\mathrm{PB}^{2}$.

Researchers adhere to practically the same opinion regarding smoking as PB risk factor (OR 2.33-5.57 [3, 5, 11]; risk is 5 times higher [9]). Beta J. et al. noted that smoking resulted in a higher risk of PB up to 34 weeks (OR 1.81) [7].

Some authors believe that alcohol intake is also a risk factor that causes PB but there are no more precise results due to a small number of observations and absence of common objective criteria (how much alcohol is consumed, how often it is taken etc.) $[5,9,19]$. In everyday medical practices doctors can rely only on "yes / no" ranking, that is, whether a women drinks alcohol during pregnancy or not.

Anthropometric parameters. Despite a lot of talks on obesity being a real epidemic nowadays, anthropometric parameters are not included into a list of risk factors that can cause $\mathrm{PB}^{2}$.

A lot of researchers revealed that a mother having low height influenced PB risks $[6,7,20]$, but N.Yu. Katkova et al. didn't reveal any dependence between a woman's height and PB frequency [3]. 
Body mass deficiency leads to a growth in PB risk depending on how apparent it is; thus, BMI 17-18.5 kg/m ${ }^{2}$ means RR equal to 0.8-1.22; BMI 16-17 kg/m², RR 0.7-1.41; BMI lower than $16 \mathrm{~kg} / \mathrm{m}^{2}$, RR 1.61-1.9 [6,21].

Overweight and obesity results in 2.4 times higher $\mathrm{PB}$ risks [9], OR amounts up to $2.08[5,6,22,23]$.

Obstetrician and gynecological case history. A lot of authors think that preterm birth in case history plays the most significant role $[3,5,6,9,12,16,24]$, and should there be two or more PB, it causes even greater risks. This factor can be found in the clinical protocol and is the most important one for determining how to treat a patient; it regulates preventive prescription of micronized progesterone and it fully corresponds to instructions attached to medications ${ }^{3}$. In this relation there have been large-scale studies over the last 5 years; they focused on examining efficiency of micronized progesterone medications prescribed to prevent $\mathrm{PB}$ and miscarriages $[25,26]$.

The clinical protocol also has data on such risk factors as one or more miscarriages at later terms and two or more medical abortions $^{3}$. Let us consider these factors in greater detail. Procedures for medical abortion have changes considerably over the last 10 years and nowadays we have two clinical protocols that regulate medical abortion at early and later terms ${ }^{3,4}$. Given that, we should revise our attitude towards abortion being a PB risk factor and clarify that it depends on a procedure applied to make an abortion.

When analyzing literature data, we noted that an issue related to dependence between abortions in previous pregnancy and PB remained disputable. Some authors believe that even one abortion or endometrectomy results in higher PB probability, especially if it is the previous pregnancy that was aborted $[6,15,24]$. The worst forecast is given in case of abortion in the previous pregnancy which was also the first one (RR 3.0 [6]) and two or more intrauterine interventions (OR 5.3 [3]). However, other authors note that it is only spontaneous miscarriage that matters (OR 2.84 [5]), and that induced abortions, ectopic and anembryonic pregnancies in case history don't result in greater PB risks $[5,9,16]$.

J. beta et al. give the most detail description of influences exerted by obstetrician case history in PB risks, but they focus only on pregnancies that ended up on $16-30^{\text {th }}$ week and $31-36^{\text {th }}$ week, one or two abortions, and absence or occurrence of birth in due time (OR from 2.33 to 18.73 depending on a combination of events) [7].

Cone biopsy or uterine neck amputation that are mentioned in the clinical protocol are also considered PB risk factors ${ }^{2}$.

All the factors that we are going to describe below are not included into the clinical protocol; still, we think it is advisable to discuss them as influence exerted by them is being studied at the moment. PB probability is related to a cesarean operation in previous births (OR up to 2.2); it grows with each subsequent operation and with stillbirth and / or early neonatal death in case history $[6,9,11,12]$.

A small break between pregnancies also results in insignificant PB risk growth; should it be less shorter than 6 months, OR amounts to 1.71 [27]); 6-11 months, OR 1.2 [27]); shorter than 18 months, OR 1.37 [11]); and a break more than 60 months results in OR varying from 1.1 to 1.5 depending on PB term [12]. A great number of births (more than 4 ) is also included into the clinical protocol as PB risk factor.

Polycystic ovary syndrome, infertility, chronic inflammation in small pelvis organs,

\footnotetext{
${ }^{3}$ Medical abortion. Clinical recommendations (treatment protocol): The Letter by the RF Public Healthcare Ministry dated October 15, 2015 No. 15-4/10/2-6120 / approved by V.N. Serov, the President of the RF Obstetricians and Gynecologists Association, 2015, $35 \mathrm{p}$.

${ }^{4}$ Induced abortion at late terms due to anomalies in fetus development. Clinical recommendations (treatment protocol): The Letter by the RF Public Healthcare Ministry dated December 04, 2018 No. 15-4/10/2-7839 / approved by V.N. Serov, the President of the RF Obstetricians and Gynecologists Association, 2018, 43 p.
} 
and uterine myoma are also considered adverse factors; however, they require further research and their influences have not been given sufficient proof $[3,5,6,9,24]$.

Somatic pathology that is included into the clinical protocol is pancreatic diabetes in its grave form and grave extragenital pathology. However, there are some research works where it is stressed that greater PB probability is caused not only by pancreatic diabetes in case history before pregnancy but especially when it is combined with smoking $(\mathrm{RR}=5.99)$ [28].

Arterial hypertension before pregnancy leads to higher PB risks depending on PB type and term and should be taken into account as it is a proven risk factor that causes preeclampsia $[5,12]$.

There are no unambiguous data on impacts exerted by anemia. Some authors state that it increases PB risks (RR 3.0 [6]), OR 1.2-1.8 depending on PB type [12]). At the same time, Ahumada et al. didn't confirm that such dependence existed [16].

It was revealed that $\mathrm{PB}$ was related to autoimmune diseases, such as rheumatoid arthritis (OR 2.1), Crohn's disease (OR 1.87), psoriasis (OR 1.88) [29], and systemic lupus erythematosus (OR 2.57-8.66 depending on how active a disease was) [30].

Few research works focus on impacts exerted by diffuse endemic goiter (OR 2.29) [5], gastrointestinal tract diseases (1.6 times higher risk [9]), mitral valve prolapse (OR 2.35 [5]). It should be noted that N. Yu. Katkova et al. didn't reveal significant influence exerted by somatic pathology on PB risk [3].

Current pregnancy and its course. If a pregnancy is due to assisted reproductive technologies (ART), than there are great risks of complications including PB; a significant role here belongs to gynecological pathology that resulted in infertility [7]. For example, according to S.V. Rishuk et al., each $4-5^{\text {th }}$ pregnancy that is due to in vitro fertilization ends up in preterm birth [31].

Multiple pregnancy also ends up in preterm birth more frequently (OR 2.4) $[16,32]$.
The worst forecast is for multiple pregnancies that are due to ART as PB probability for them varies from 80 to $100 \%[33,34]$.

Both these factors (ART and multiple pregnancy) are included into the clinical protocoal ${ }^{2}$.

Placental pathology. According to several authors, placenta incompetence authentically frequently occurs in women with preterm births in case history and it can be due to a common pathogenetic mechanism (RR 2.6 [24]; OR 14.5 [3]). At the same time Dyadichkina et al. didn't confirm such data [5]. We should note that placenta incompetence in itself as well as ways how to prevent and treat this pregnancy-related complication are to be discussed more profoundly. However, such a complication as fetal hydrops which is caused by functional disorders in fetus-placental complex is a commonly recognized $\mathrm{PB}$ risk factor ${ }^{2}$. According to the clinical protocol, only pathological placenta location and premature detachment of a normally located placenta are PB risk factors ${ }^{2}$.

Patients that suffer from preeclampsia run well-proven higher PB risk (OR 1.9 [16]; 4.43 [35]; 6.9-89.7 depending on PB type [12]). But the clinical protocol that is valid at the moment doesn't list preeclampsia among risk factors that can cause PB in a current pregnancy; probably, this disease should be assigned into a category that includes grave extragenital pathologies ${ }^{2}$.

Infectious diseases during pregnancy induce a whole cascade of systemic inflammatory reactions and it is a pathologic section in PB mechanism [3]. There are data on impacts exerted by acute viral infections [5, 24], urinary infections including inapparent bacteriuria [36, 37]; cervical-vaginal infections $[5,9,24]$.

Parodentium diseases, together with all the above mentioned infections, are also considered to be risk factors as pathogenic flora from parodentium can occur in placenta tissues [38]. N.N. Trigolos et al. confirmed that oral cavity infections occurred 5 times more frequently among women with PB [39], and Gesase N. noted that PB occur more frequently 
among women with parodentium infections, OR 2.32 [40].

The clinical protocol stresses that any uterine bleedings during a current pregnancy are a risk factor that can cause $\mathrm{PB}^{2}$, and it is indisputable. On the contrary, a threatened miscarriage during the first half of a pregnancy can still be discussed. Several domestic researchers proved that a threatened miscarriage resulted in lower chances that a pregnancy would end up in due time (OR 2.45 [5]; $x^{2}=5.41$ [41]; RR 2.4 [24]), and a threatened miscarriage in the second trimester caused higher PB risks than the same threat in the first one (RR 3.8 [24]; by $62.7 \%$ [41]). However, precise criteria for diagnosing "a threatened miscarriage" were determined in 2016 only in the clinical recommendations entitled "Miscarriage at early stages of a pregnancy: diagnostics and treatment procedures". A threatened miscarriage involves scanty bloody discharge from genital tracts. It allows stating that it is uterine bleedings during a current pregnancy that should be investigated in research works as it will make for data obtained by different authors being quite comparable.

A group of Chinese researchers performed meta-analysis of research works that focused on vitamin D deficiency; they revealed that when vitamin $D$ concentrations in blood dropped lower than $20 \mathrm{ng} / \mathrm{ml}$, PB risks grew (OR 1.29) [42]. Flood-Nichols S.K. et al. noted that there was no statistically significant discrepancy between various groups as per PB frequency when vitamin D concentrations in blood were lower than $30 \mathrm{ng} / \mathrm{ml}$ [43]. It was also confirmed by L. Yang et al. as they didn't reveal any dependence between BP and vitamin D deficiency [44]. Nowadays medical experts are trying to develop a project of clinical recommendations on how to prevent and treat vitamin D defi- ciency before pregnancy, during it, and after childbirth as well.

Any relation between zinc deficiency and PB probability is also to be discussed as there is no unambiguous evidence on the matter [45].

Surgeries and injuries are also factors that can cause PB and it is indisputable ${ }^{2}$.

We should give special attention to preterm cervical maturation or cervical incompetence as it is a commonly recognized PB risk factor (OR 2.45 [5]; RR 39.8 for uterine neck length being $25 \mathrm{~mm}$ and shorter in the $2^{\text {nd }}$ trimester [46]). In 2018 clinical recommendations on cervical incompetence were published; according to them, there are predisposing factors that can cause this pathology ${ }^{6}$.

Domestic researchers mention other risk factors that cause cervical incompetence in their works. N.A. Linchenko et al. stated that a risk group as per cervical incompetence probability included women with overweight, obesity, 3 or more pregnancies, miscarriages at later terms, with two or more intrauterine interventions in case history, with chronic inflammations in small pelvis organs, surgeries on ovaries, and infertility in case history [47]. M.M. Padrul et al. determined only one risk factor that resulted in discrepancies between groups with cervical incompetence and without it; it was spontaneous late miscarriage or PB in case history $\left(x^{2}=5.04\right)$ [48]. Yu.D. Kaplan et al. revealed several risk factors that could cause late spontaneous miscarriages and spontaneous PB among women with treated cervical incompetence. They were combined late spontaneous miscarriages and spontaneous $\mathrm{PB}$ in case history and a threatened miscarriage during a current pregnancy, a higher contribution being made by this threat during the $2^{\text {nd }}$ trimester [49]. V.I. Chernyaeva et al. highlighted the fol-

\footnotetext{
${ }^{5}$ Miscarriage at early stages of a pregnancy: diagnostics and treatment procedures. Clinical recommendations (treatment protocol): The Letter by the RF Public Healthcare Ministry dated June 07, 2016 No. 15-4/10/2-34820 / approved by V.N. Serov, the President of the RF Obstetricians and Gynecologists Association, 2016, 33 p.

${ }^{6}$ On clinical recommendations (treatment protocol) "Cervical incompetence": The Letter by the RF Public Healthcare Ministry dated December 28, 2018 No. 15-4/10/2-7991. KonsultantPlus. Available at: http://www.consultant.ru/document/cons_doc_LAW_320915/(22.09.2019).
} 
lowing risk factors in case history that could cause cervical incompetence: late abortions and $\mathrm{PB}$; two or more intrauterine interventions; surgeries on uterine neck. They also spotted out risk factors that were related to a current pregnancy; they were a threatened miscarriage; acute respiratory infections; acute pyelonephritis; acute vulvovaginitis; preeclampsia [50]. Taking into account available literature data, it seems advisable to compare existing research works on risk factors that cause PB and cervical incompetence (Table). As we can see from the Table, risk factors causing PB and cervical incompetence coincide partly; some of them, however, cause only cervical incompetence. The situation doesn't seem adequate to us and allows us to include risk factors that cause cervical incompetence into the list of factors that cause PB.

Risk factors that cause preterm birth and cervical incompetence (CI)

\begin{tabular}{|c|c|c|c|}
\hline \multirow{2}{*}{ Risk factor } & \multicolumn{2}{|l|}{ Preterm birth } & \multirow{2}{*}{$\begin{array}{c}\text { CI } \\
+\end{array}$} \\
\hline & + & - & \\
\hline $\begin{array}{l}\text { Senior age } \\
\text { Young age }\end{array}$ & 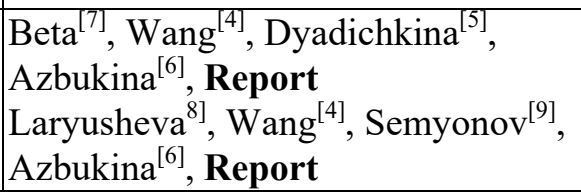 & $\begin{array}{l}\text { Wong }^{[11]} \\
\text { Katkova }^{[3]} \\
\text { Sujan }^{[10]}\end{array}$ & \\
\hline Low social and economic status & Katkova $^{[3]}$, Report & & \\
\hline Stress & Gravett $^{[13]}$, Report & & \\
\hline Unemployed women & Azbukina $^{[6]}$, Semyonov $^{[9]}$, Casas $^{[14]}$ & & \\
\hline Without higher education & Katkova $^{[3]}$, Semyonov $^{[9]}$ & & \\
\hline Single & Semyonov $^{[9]}$ & Dyadichkina $^{[5]}$ & \\
\hline Age of coitarche & Semyonov $^{[9]}$ & & \\
\hline Prenatal observation quality & $\begin{array}{l}\text { Leneuve-Dorilas }{ }^{[15]} \text {, Ahumada- } \\
\text { Barrios }^{[16]}\end{array}$ & & \\
\hline Physical loads & Portela $^{[17]}$ & Silva ${ }^{[18]}$ & \\
\hline Smoking & $\begin{array}{l}\text { Wong }^{[1]]} \text {, Dyadichkina } \\
\text { Semyonov }^{[5]}, \text { Beta }^{[7]} \text {, Report }\end{array}$ & & \\
\hline Alcohol intake & $\begin{array}{l}\text { Green }^{[19]}, \text { Semyonov }^{[9]} \\
\text { Dyadichkina }^{[5]}, \text { Report }\end{array}$ & & \\
\hline $\begin{array}{l}\text { Intake of anti-tumor hormonal } \\
\text { preparations }\end{array}$ & & & Report \\
\hline African American & Jelliffe-Pawlowski $^{[12]}$, Beta $^{[7]}$ & Wong $^{[11]}$ & \\
\hline CI in the closest female relatives & & & Report \\
\hline Low body height & Azbukina $^{[6]}$, Beta $^{[7]}$, Morisaki ${ }^{[20]}$ & Katkova $^{[3]}$ & \\
\hline Body mass deficiency & Azbukina $^{[6]}$, Girsen $^{[21]}$ & & \\
\hline Overweight and obesity & $\begin{array}{l}\text { Semyonov }{ }^{[9]}, \text { Dyadichkina }^{[5]} \text {, Azbuki- } \\
\text { na }^{[6]}, \text { Katkova }^{[3]}, \mathrm{Ju}^{[22} \text {, Dudenhausen }{ }^{[23]}\end{array}$ & & $\begin{array}{l}\text { Linchenko }^{[47]}, \\
\text { Report }\end{array}$ \\
\hline 3 or more pregnancies & Nabeeva $^{[24]}$ & & Linchenko $^{[47]}$ \\
\hline More than 4 births & Report & & \\
\hline Preterm birth in case history & 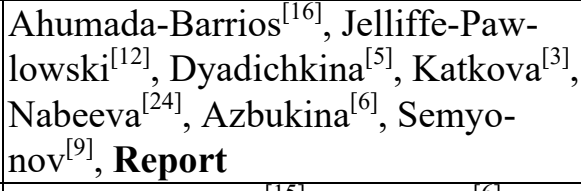 & & $\begin{array}{l}\text { Padrul }{ }^{[48]}, \\
\text { Черняева }^{[50]} \\
\text { Report }\end{array}$ \\
\hline Abortion at early stages & $\begin{array}{l}\text { Leneuve-Dorilas }{ }^{[15]}, \text { Azbukina }^{[6]}, \\
\text { Nabeeva }\end{array}$ & $\begin{array}{l}\text { Semyonovov } \\
\text { Dyadichkina }^{[9]}\end{array}$ & \\
\hline $\begin{array}{l}\text { Spontaneous miscarriage at } \\
\text { early stages }\end{array}$ & Dyadichkina $^{[5]}$ & & \\
\hline
\end{tabular}




\begin{tabular}{|c|c|c|c|}
\hline \multirow{2}{*}{ Risk factor } & \multicolumn{2}{|l|}{ Preterm birth } & \multirow{2}{*}{$\begin{array}{c}\mathrm{CI} \\
+\end{array}$} \\
\hline & + & - & \\
\hline $\begin{array}{l}\text { Spontaneous miscarriage at later } \\
\text { stages }\end{array}$ & Beta $^{[7]}$, Report & & $\begin{array}{l}\text { Linchenko }^{[47]}, \\
\text { Padrul } \\
\text { Chernyaeva }^{[48]} \\
\text { Report }\end{array}$ \\
\hline $\begin{array}{l}\text { Spontaneous miscarriages at later } \\
\text { stages }+ \text { preterm birth in case his- } \\
\text { tory }\end{array}$ & & & Kaplan $^{[49]}$ \\
\hline $\begin{array}{l}2 \text { or more intrauterine } \\
\text { interventions }\end{array}$ & Katkova $^{[3]}$, Report & & $\begin{array}{l}\text { Linchenko }^{[47]}, \\
\text { Chernyaeva }^{[48]} \\
\text { Report }\end{array}$ \\
\hline Cesarean section in previous births & Wong $^{[11]}$, Jelliffe-Pawlowski ${ }^{[12]}$ & & \\
\hline Perinatal losses & Azbukina $^{[6]}$, Semyonov $^{[9]}$ & & \\
\hline $\begin{array}{l}\text { A short break between pregnancies } \\
\text { Long breaks between pregnancies }\end{array}$ & $\begin{array}{l}\text { Shachar }{ }^{[27]}, \text { Wong }^{[11]} \\
\text { Jelliffe-Pawlowski }^{[12]}\end{array}$ & & \\
\hline Hormonal disorders & Azbukina $^{[6]}$ & & \\
\hline Polycystic ovary syndrome & Dyadichkina $^{[5]}$ & & Report \\
\hline Hyperandrogenism & & & Report \\
\hline Lack of progesterone & & & Report \\
\hline Genital infantilism & & & Report \\
\hline Uterine malformations & & & Report \\
\hline Infertility & Dyadichkina $^{[5]}$ & & Linchenko $^{[47]}$ \\
\hline $\begin{array}{l}\text { Inflammatory diseases in small } \\
\text { pelvis organs }\end{array}$ & Nabeeva $^{[24]}$, Semyonov $^{[9]}$ & $\begin{array}{l}\text { Dyadichkina }^{[5]}, \\
\text { Katkova }^{[3]}\end{array}$ & $\begin{array}{l}\text { Linchenko }^{[47]} \text {, } \\
\text { Report }\end{array}$ \\
\hline Surgeries on ovaries & & & Linchenko $^{[47]}$ \\
\hline Uterine myoma & Nabeeva $^{[24]}$ & & \\
\hline Surgeries on uterine neck & Report & & $\begin{array}{l}\text { Chernyaeva }{ }^{[50]} \\
\text { Report }\end{array}$ \\
\hline $\begin{array}{l}\text { Congenital shortening of uterine } \\
\text { neck }\end{array}$ & & & Report \\
\hline Uncured cervical raptures & & & Report \\
\hline Somatic pathology & Report & Katkova $^{[3]}$ & \\
\hline $\begin{array}{l}\text { Arterial hypertension before } \\
\text { pregnancy }\end{array}$ & $\begin{array}{l}\text { Dyadichkina }{ }^{[5]} \text {, Jelliffe-Pawlow- } \\
\text { ski }^{[12]}, \text { Semyonov }^{[9]}\end{array}$ & & \\
\hline $\begin{array}{l}\text { Pancreatic diabetes before preg- } \\
\text { nancy }\end{array}$ & Jelliffe-Pawlowski $^{[12]}$, Borsari $^{[28]}$ & & \\
\hline Thyroid gland diseases & Dyadichkina $^{[5]}$ & & \\
\hline 2 and 3 degree anemia & Azbukina $^{[6]}$, Jelliffe-Pawlowski ${ }^{[12]}$ & $\begin{array}{l}\text { Ahumada- } \\
\text { Barrios }^{[16]}\end{array}$ & Report \\
\hline $\begin{array}{l}\text { Autoimmune diseases and colla- } \\
\text { genosis }\end{array}$ & Bandoli $^{[29]}$, Skorpen $^{[30]}$ & & Report \\
\hline Mitral valve prolapse & Dyadichkina $^{[5]}$ & & \\
\hline Digestive tract diseases & Semyonov $^{[9]}$ & & \\
\hline Assisted reproductive technologies & Beta $^{[7]}, \mathrm{R}^{[31]}$, Report & & \\
\hline Multiple pregnancy & $\begin{array}{l}\text { Ahumada-Barrios }{ }^{[16]}, \text { Arkhipov }^{32]} \text {, } \\
\text { Report }\end{array}$ & & Report \\
\hline $\begin{array}{l}\text { Assisted reproductive technolo- } \\
\text { gies + multiple pregnancy }\end{array}$ & Egorova $^{[33]}$, Perepelitsa ${ }^{[34]}$ & & \\
\hline Pathological placenta location & Nabeeva ${ }^{[24]}$, Report & & \\
\hline Placenta incompetence & Nabeeva $^{[24]}$, Katkova $^{[3]}$ & Dyadichkina $^{[5]}$ & \\
\hline Hydramnios & Report & & Report \\
\hline
\end{tabular}




\begin{tabular}{|c|c|c|c|}
\hline \multirow{2}{*}{ Risk factor } & \multicolumn{2}{|l|}{ Preterm birth } & $\mathrm{CI}$ \\
\hline & + & - & + \\
\hline Preeclampsia & $\begin{array}{l}\text { Ahumada-Barrios }{ }^{[16]}, \text { Davies }^{[35]} \text {, } \\
\text { Jelliffe-Pawlowski }^{[12]}\end{array}$ & & Chernyaeva ${ }^{[50]}$ \\
\hline $\begin{array}{l}\text { Threat of miscarriage in the } \\
1^{\text {st }} \text { trimester }\end{array}$ & $\begin{array}{l}\text { Dyadichkina }^{[5]}, \text { Cherepakhin }^{[41]} \text {, } \\
\text { Nabeeva }^{[24]} \text {, Report }\end{array}$ & & $\begin{array}{l}\text { Kaplan }^{[49]}, \\
\text { Chernyaeva }^{[50]}\end{array}$ \\
\hline $\begin{array}{l}\text { Threat of miscarriage in the } \\
2^{\text {nd }} \text { trimester }\end{array}$ & Cherepakhin $^{[41]}$, Nabeeva ${ }^{[24]}$, Report & & $\begin{array}{l}\text { Kaplan }^{[49]}, \\
\text { Chernyaeva }^{[50]}\end{array}$ \\
\hline Infectious diseases & 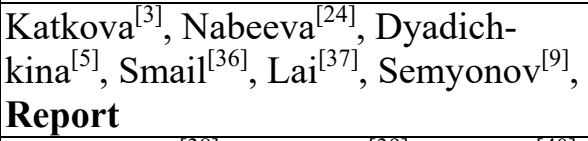 & & $\begin{array}{l}\text { Chernyaeva }{ }^{[50]}, \\
\text { Report }\end{array}$ \\
\hline Parodentium diseases & $\begin{array}{l}\text { Akhil'gova }{ }^{[38]}, \text { Trigolos }^{[39]}, \text { Gesase }^{[40]} \text {, } \\
\text { Report }\end{array}$ & & \\
\hline Vitamin D deficiency & Qin $^{[42]}$ & $\begin{array}{l}\text { Flood-Nichols }{ }^{[43]}, \\
\text { Yang }^{[44]}\end{array}$ & \\
\hline Zinc deficiency & Wilson $^{[45]}$ & & \\
\hline Cervical incompetence & $\begin{array}{l}\text { Dyadichkina }{ }^{[5]}, \text { Nabeeva }^{[24]}, \text { Wulff }^{[46]} \text {, } \\
\text { Report }\end{array}$ & & \\
\hline
\end{tabular}

Therefore, in spite of multiple research works that focus on PB etiology, the issue still remains extremely vital. Should a complete list of $\mathrm{PB}$ risk factor be created, it will allow optimizing not only a system for ranking patients as per their risk groups, but also performing adequate PB prevention. Prevention activities are first of all aimed at reducing a number of extremely early pre-term births and at improv- ing neonatal outcomes. This goal can be achieved due to organizing a qualitative system for predicting obstetrician complications including pre-term birth.

Funding. The research was not granted any sponsor support.

Conflict of interests: the authors declare there is no any conflict of interests.

\section{References}

1. Olina A.A., Sadykova G.K. Premature labor. Yesterday, today, tomorrow. Ural'skii meditsinskii zhurnal, 2019, vol. 5, no. 173, pp. 49-55 (in Russian).

2. Khodzhaeva Z.S., Guseynova G.E., Gorina K.A. Preterm labor: Current problems of obstetrics management. Meditsinskii opponent, 2018, no. 2, pp. 70-76 (in Russian).

3. Katkova N.Yu., Bodrikova O.I., Bezrukova I.M. Clinical and Anamnestic Features of Different Types of Premature Birth [Retrospective Review]. Effektivnaya farmakoterapiya, 2017, no. 26, pp. 12-16 (in Russian).

4. Wang C., Wang X.Y., Yang H.X. Effect of maternal age on pregnancy outcomes in Beijing. Zhonghua Fu Chan Ke Za Zhi, 2017, vol. 52, no. 8, pp. 514-520. DOI: 10.3760/cma.j.issn. 0529-567X.2017.08.003

5. Dyadichkina O.V., Radetskaya L.E., Zan'ko S.N. Risk factors for preterm birth in Belarus. Mat' i ditya v Kuzbasse, 2015, vol. 62, no. 3, pp. 31-36 (in Russian).

6. Azbukina L.N., Manucharov A.A. Faktory riska i prognozirovanie prezhdevremennykh rodov [Preterm birth: risk factors and prediction]. Vestnik Pridnestrovskogo universiteta, seriya: medikobiologicheskie i khimicheskie nauki, 2013, vol. 2, no. 44, pp. 7-10 (in Russian).

7. Beta J., Akolekar R., Ventura W., Syngelaki A., Nicolaides K.H. Prediction of spontaneous preterm delivery from maternal factors, obstetric history and placental perfusion and function at 11-13 weeks. Prenat Diagn, 2011, vol. 31, no. 1, pp. 75-83. DOI: 10.1002/pd.2662

8. Laryusheva T.M., Istomina N.G., Baranov A.N. Comparative study of the clinical parameters of pregnancy and childbirth in teenagers and women of the optimal reproductive age. Zhurnal akusherstva $i$ zhenskikh boleznei, 2016, vol. 65, no. 1, pp. 34-42 (in Russian). 
9. Semenov Yu.A., Chulkov V.S., Sakharova V.V., Moskvicheva M.G. Assessment of risk factors for preterm birth in women with preterm pregnancy. Sovremennye problem nauki i obrazovaniya, 2015, no. 4, pp. 493-494 (in Russian).

10. Sujan A.C., Rickert M.E., Class Q.A., Coyne C.A., Lichtenstein P., Almqvist C., Larsson H., Sjölander A. Behav A Genetically Informed Study of the Associations Between Maternal Age at Childbearing and Adverse Perinatal Outcomes. Genet, 2018, vol. 46, no. 3, pp. 431-456. DOI: 10.1007/s10519-015-9748-0

11. Wong L.F., Wilkes J., Korgenski K., Varner M.W., Manuck T.A. Risk factors associated with preterm birth after a prior term delivery. BJOG, 2016, vol. 123, no. 11, pp. 1772-1778. DOI: 10.1111/1471-0528.13683

12. Jelliffe-Pawlowski L.L., Baer R.J., Blumenfeld Y.J., Ryckman K.K., O'Brodovich H.M., Gould J.B., Druzin M.L., El-Sayed Y.Y. Maternal characteristics and mid-pregnancy serum biomarkers as risk factors for subtypes of preterm birth. BJOG, 2015, vol. 122, no. 11, pp. 1484-1493. DOI: 10.1111/1471-0528.13495

13. Gravett M.G., Craig E., Rubens C.E. Global report on preterm birth and stillbirth (2 of 7): discovery science. BMC Pregnancy and Childbirth, 2010, no. 10, suppl. 1, pp. S2-S3. DOI: 10.1186/1471-2393-10-S1-S2

14. Casas M., Cordier S., Martínez D., Barros H., Bonde J.P., Burdorf A., Costet N., Dos Santos A.C. [et al.]. Maternal occupation during pregnancy, birth weight, and length of gestation: combined analysis of 13 European birth cohorts. Scand. J. Work Environ Health, 2015, vol. 41, no. 4, pp. 384-396. DOI: 10.5271/sjweh.3500

15. Leneuve-Dorilas M., Favre A., Carles G., Louis A., Nacher M. Risk factors for premature birth in French Guiana: the importance of reducing health inequalities. J. Matern. Fetal. Neonatal. Med, 2019, vol. 32, no. 8, pp. 1388-1396. DOI: 10.1080/14767058.2017.1403578

16. Ahumada-Barrios M.E., Alvarado G.F. Risk Factors for premature birth in a hospital. Rev. Lat. Am. Enfermagem, 2016, no. 24, pp. e2750. DOI: 10.1590/1518-8345.0775.2750

17. Portela S.N., Rocha-de-Souza R., Oppermann-Lisboa K., Donatto G.B., Dal Bosco S.N., El Beitune P. Maternal physical activity, cervical length and its relation to spontaneous vaginal birth at term. Arch. Gynecol. Obstet, 2014, vol. 290, no. 2, pp. 257-262. DOI: 10.1007/s00404-014-3199-4

18. Silva S.G., Hallal P.C., Domingues M.R., Bertoldi A.D., Silveira M.F.D., Bassani D., Da Silva I.C.M., Da Silva B.G.C. [et al.]. A randomized controlled trial of exercise during pregnancy on maternal and neonatal outcomes: results from the PAMELA study. Int. J. Behav. Nutr. Phys. Act., 2019, vol. 14, no. 1, pp. 175. DOI: 10.1186/s12966-017-0632-6

19. Green P.P., McKnight-Eily L.R., Tan C.H., Mejia R., Denny C.H. Vital Signs: Alcohol-Exposed Pregnancies. United States, 2011-2013. MMWR Morb. Mortal. Wkly. Rep., 2016, vol. 65, no. 4, pp. 91-97. DOI: $10.15585 / \mathrm{mmwr} . \mathrm{mm} 6504 \mathrm{a6external}$

20. Morisaki N., Ogawa K., Urayama K.Y., Sago H., Sato S., Saito S. Preeclampsia mediates the association between shorter height and increased risk of preterm delivery. Int. J. Epidemiol., 2019, vol. 46, no. 5, pp. 1690-1698. DOI: 10.1093/ije/dyx 107

21. Girsen A.I., Mayo J.A., Carmichael S.L., Phibbs C.S., Shachar B.Z., Stevenson D.K., Lyell D.J., Shaw G.M. [et al.]. Women's prepregnancy underweight as a risk factor for preterm birth: a retrospective study. BJOG, 2016, vol. 123, no. 12, pp. 2001-2007. DOI: 10.1111/1471-0528.14027

22. Ju A.C., Heyman M.B., Garber A.K., Wojcicki J.M. Maternal Obesity and Risk of Preterm Birth and Low Birthweightin Hawaii PRAMS, 2000-2011. Matern. Child. Health. J., 2019, vol. 22, no. 6, pp. 893-902. DOI: $10.1007 / \mathrm{s} 10995-018-2464-7$

23. Dudenhausen J.W., Kunze M., Wittwer-Backofen U., Hagenah H.P., Strauss A., Günther V., Alkatout İ., Grunebaum A., Voigt M. The relationship between maternal age, body mass index, and the rate of preterm birth. J. Turk. Ger. Gynecol. Assoc., 2019, vol. 19, no. 4, pp. 182-186. DOI: 10.4274/jtgga.2018.0057

24. Nabeeva D.A., Semenova M.V. Types of pregravid preparation in light of risk factors of early preterm delivery in the Udmurt republic. Meditsinskii vestnik Bashkortostana, 2014, vol. 9, no. 6, pp. 81-83 (in Russian).

25. Savel'eva G.M., Aksenenko V.A., Andreeva M.D., Bazina M.I., Bashmakova N.V., Borovkova L.V., Bryukhina E.V., Bushtyreva I.O. [et al.]. Micronized progesterone therapy of recurrent pregnancy loss (results of multicenter TRISTAN-1 study). Akusherstvo i ginekologiya, 2017, no. 11, pp. 44-55 (in Russian).

26. Romero R., Conde-Agudelo A., Da Fonseca E., O'Brien J.M., Cetingoz E., Creasy G.W., Hassan S.S., Nicolaides K.H. Vaginal Progesterone for Preventing Preterm Birth and Adverse Perinatal Out- 
comes in Singleton Gestations with a Short Cervix: A Meta-Analysis of Individual Patient Data. American Journal of Obstetrics and Gynecology, 2017, vol. 218, no. 2, pp. 161-180. DOI: 10.1016/j.ajog.2017.11.576

27. Shachar B.Z., Mayo J.F., Lyell D.J., Baer R.J., Jeliffe-Pawlowski L.L., Stevenson D.K., Shaw G.M. Interpregnancy interval after live birth or pregnancy termination and estimated risk of preterm birth: a retrospective cohort study 2009-2017. BJOG, 2016, vol. 123, no. 12, pp. 2009-2017. DOI: $10.1111 / 1471-0528.14165$

28. Borsari L., Malagoli C., Werler M.M., Rothman K.J., Malavolti M., Rodolfi R., De Girolamo G., Nicolini F., Vinceti M. Joint Effect of Maternal Tobacco Smoking and Pregestational Diabetes on Preterm Births and Congenital Anomalies: A Population-Based Study in Northern Italy. Journal of Diabetes Research, 2016, no. 2782741, pp. 1-7. DOI: 10.1155/2018/2782741

29. Bandoli G., Chambers C.D. Autoimmune conditions and comorbid depression in pregnancy: examining the risk of preterm birth and preeclampsia. J. Perinatol, 2019, vol. 37, no. 10, pp. 1082-1087. DOI: $10.1038 /$ jp.2017.109

30. Skorpen C.G., Lydersen S., Gilboe I.M., Skomsvoll J.F., Salvesen K.Å., Palm Ø., Svean Koksvik H.S., Jakobsen B., Wallenius M. Influence of disease activity and medications on offspring birth weight, preeclampsia and preterm birth in systemic lupus erythematosus: a population-based study. Ann. Rheum. Dis, 2019, vol. 77, no. 2, pp. 264-269. DOI: 10.1136/annrheumdis-2017-211641

31. Rishchuk S.V., Dushenkova T.A., Mirskii V.E. Assisted reproductive technologies and health of population. Meditsinskii al'manakh, 2014, vol. 4, no. 34, pp. 71-74 (in Russian).

32. Arkhipov V.V., Kulavskii E.V., Arkhipov V.V., Kulavskii V.A. Multifoetus pregnancy is the risk of birth giving before time. Mat' i ditya v Kuzbasse, 2012, no. S1, pp. 13-19 (in Russian).

33. Egorova A.T., Ruppel' N.I., Maiseenko D.A. Terms and methods of delivery when induced multiple pregnancy. Mat' i ditya v Kuzbasse, 2015, vol. 2, no. 61, pp. 34-37 (in Russian).

34. Perepelitsa S.A., Golubev A.M., Moroz V.V. Osobennosti techeniya mnogoplodnoi beremennosti i predposylki dlya nastupleniya prezhdevremennykh rodov i razvitiya RDS u nedonoshennykh novorozhdennykh [Peculiarities of multiple pregnancy and its clinical course; preconditions for preterm birth and RDS (respiratory-distress syndrome) in premature newborns]. Byulleten' federal'nogo tsentra serdtsa, krovi i endokrinologii im. V.A. Almazova, 2010, no. 6, pp. 53-54 (in Russian).

35. Davies E.L., Bell J.S., Bhattacharya S. Preeclampsia and preterm delivery: A populationbased case-control study. Hypertens Pregnancy, 2016, vol. 35, no. 4, pp. 510-519. DOI: 10.1080/ 10641955.2016.1190846

36. Smaill F.M., Vazquez J.C. Antibiotics for asymptomatic bacteriuria in pregnancy. Cochrane Database Syst. Rev., 2015, no. 8, pp. CD000490. DOI: 10.1002/14651858.cd000490.pub3

37. Lai Y.J., Hsu T.Y., Lan K.C., Lin H., Ou C.Y., Fu H.C., Tsai C.C. Asymptomatic pyuria in pregnant women during the first trimester is associated with an increased risk of adverse obstetrical outcomes. Taiwan J. Obstet. Gynecol., 2017, no. 56, pp. 192-195. DOI: 10.1016/j.tjog.2016.04.040

38. Akhil'gova Z.S. Periodontitis diseases and premature parturition (literature review). Vestnik novykh meditsinskikh tekhnologii. Elektronnoe izdanie, 2018, no. 1, pp. 159-166 (in Russian).

39. Trigolos N.N., Firsova I.V., Makedonova Yu.A., Ergieva S.I. Chronic infections of the mouth as a factor the risk of premature birth and low birth weight. Fundamental'nye issledovaniya, 2013, vol. 12, no. 1, pp. 85-88 (in Russian).

40. Gesase N., Miranda-Rius J., Brunet-Llobet L., Lahor-Soler E., Mahande M.J., Masenga G. The association between periodontal disease and adverse pregnancy outcomes in Northern Tanzania: a crosssectional study. Afr. Health. Sci., 2018, vol. 18, no. 3, pp. 601-611. DOI: 10.4314/ahs.v18i3.18

41. Cherepakhin E.P., Novikova V.A., Tomashevskii D.V., Khorol'skii V.A., Yugina A.A. Peculiarities of anamnesis and complications of pregnancy in the I-II trimesters and preterm birth risk. Kubanskii nauchnyi meditsinskii vestnik, 2017, vol. 24, no. 4, pp. 150-155 (in Russian).

42. Qin L.L., Lu F.G., Yang S.H., Xu H.L., Luo B.A. Does Maternal Vitamin D Deficiency Increase the Risk of Preterm Birth: A Meta-Analysis of Observational Studies. Nutrients, 2016, vol. 8, no. 5. DOI: 10.3390/nu8050301

43. Flood-Nichols S.K., Tinnemore D., Huang R.R. [et al.]. Vitamin D Deficiency in Early Pregnancy. PLoS ONE, 2010, vol. 10, no. 4, pp. e0123763. DOI: 10.1371/journal.pone.0123763

44. Yang L., Pan S., Zhou Y., Wang X., Qin A., Huang Y., Sun S. Correlation Between Serum Vitamin D Deficiency and Preterm Birth. Med. Sci. Monit, 2016, no. 22, pp. 4401-4405. DOI: 10.12659/msm.898117 
45. Wilson R.L., Grieger J.A., Bianco-Miotto T., Roberts C.T. Association between Maternal Zinc Status, Dietary Zinc Intake and Pregnancy Complications: A Systematic Review. Nutrients, 2016, vol. 8, no. 10, pp. E641. DOI: 10.3390/nu8100641

46. Wulff C.B., Rode L., Rosthøj S., Hoseth E., Petersen O.B., Tabor A. Transvaginal sonographic cervical length in first and second trimesters in a low-risk population: a prospective study. Ultrasound Obstet Gynecol., 2018, vol. 51, no. 5, pp. 604-613. DOI: 10.1002/uog.17556

47. Linchenko N.A., Andreeva M.V., Shevtsova E.P. Preterm labor and cervical insufficiency. Prognosis and prevention. Mat' i ditya v Kuzbasse, 2015, vol. 2, no. 61, pp. 66-69 (in Russian).

48. Padrul' M.M., Olina A.A., Klyausova E.G., Sadykova G.K. Prevention of preterm delivery in the first trimester of pregnancy. Akusherstvo i ginekologiya, 2015, no. 10, pp. 107-111 (in Russian).

49. Kaplan Yu.D., Zakharenkova T.N. Miscarriage causes in women with cervical correction. Problemy zdorov'ya i ekologii, 2017, vol. 54, no. 4, pp. 17-21 (in Russian).

50. Chernyaeva V.I., Neudakhina I.O., Zarechneva T.A. Pregnancy course and birth outcomes in women with cervical in sufficiency. Fundamental'naya i klinicheskaya meditsina, 2016, vol. 2, no. 1, pp. 70-75 (in Russian).

Padrul' M.M., Galinova I.V., Olina A.A., Sadykova G.K. Stratification of preterm birth risk: peculiarities. Health Risk Analysis, 2020, no. 1, pp. 165-176. DOI: 10.21668/health.risk/2020.1.17.eng

Received: 07.10.2019

Accepted: 27.11.2019

Published: 30.03 .2020 